NBER WORKING PAPER SERIES

\title{
THE IMPACTS OF AN EAST ASIA FTA \\ ON FOREIGN TRADE IN EAST ASIA
}

\author{
Shujiro Urata \\ Kozo Kiyota \\ Working Paper 10173 \\ http://www.nber.org/papers/w10173
}

\author{
NATIONAL BUREAU OF ECONOMIC RESEARCH \\ 1050 Massachusetts Avenue \\ Cambridge, MA 02138 \\ December 2003
}

The authors would like to thank Dukgeun Ahn, Philippa Dee, Kyoji Fukao, Takatoshi Ito, Erlinda Medalla, Andrew Rose, Robert M. Stern and the seminar participants at the Fourteenth Annual East Asian Seminar on Economics titled "International Trade," in Taipei, Taiwan, September 5-7, 2003, for their helpful comments and suggestions on the earlier version of the paper. Any remaining errors are the authors' alone. Kozo Kiyota was a Visiting Scholar at the University of Michigan, Ann Arbor, when the present version of the paper was prepared and would like to thank the Kikawada Fellowship Program for providing financial support for this research. The views expressed herein are those of the authors and not necessarily those of the National Bureau of Economic Research.

(C2003 by Shujiro Urata and Kozo Kiyota. All rights reserved. Short sections of text, not to exceed two paragraphs, may be quoted without explicit permission provided that full credit, including $(\subset$ notice, is given to the source. 
The Impacts of an East Asia FTA on Foreign Trade in East Asia

Shujiro Urata and Kozo Kiyota

NBER Working Paper No. 10173

December 2003

JEL No. F17, F13, F15

\begin{abstract}
This paper attempts to examine the impact of an East Asia FTA on trade patterns in East Asia by using a multisector computable general equilibrium model. The model used in this analysis is the standard GTAP model and GTAP database developed by Hertel (1997) and his colleagues of Purdue University. Our findings are summarized as follows: First, the impacts of an East Asia FTA on GDP and welfare of member countries are generally positive, while the impacts on non-members are negative. Second, and surprisingly, the FTA does not seem to affect much on the patterns of comparative advantage or intra-industry trade. Third, production of the sectors with a comparative advantage increases. Fourth, unexpectedly, exports of protected sectors increase, reflecting a shift in incentives from domestic sales to export sales. Finally, an East Asia FTA will promote regionalization in East Asia but it will not necessarily promote regionalization in AFTA.

Shujiro Urata

School of Social Sciences

Waseda University

1-6-1 Nishiwaseda

Shinjuku-ku, Tokyo

169-8050 Japan

surata@waseda.jp

Kozo Kiyota

Faculty of Business Administration

Yokohama National University

79-4 Tokiwadai

Hodogaya-ku, Yokohama

240-8501 Japan

kiyota@ynu.ac.jp
\end{abstract}


The Impacts of an East Asia FTA on Foreign Trade in East Asia

\author{
Shujiro Urata and Kozo Kiyota
}

\title{
1. Introduction
}

The world economy has been witnessing the surge in free trade agreements (FTA) since the early 1990s. Up to December 2002, some 250 FTAs have been notified to the GATT/WTO, and of those 130 were notified after the establishment of the WTO in January 1995. ${ }^{1}$ More than 170 FTAs are currently in force, and additional 70 FTAs are expected to be operational, although not yet notified. According to the WTO, by the end of 2005, if FTAs reportedly planned or already under negotiation are concluded, the total number of FTAs in force may approach 300. Among the regions of the world East Asia were not active in establishing FTAs until recently. Indeed, until 2002, when Japan-Singapore FTA was enacted, ASEAN Free Trade Area (AFTA) was the only major FTA in the region. Many East Asian economies started showing a strong interest in FTAs toward the end of the 1990s. Although East Asia has so far seen the creation of only few FTAs including AFTA and Japan-Singapore FTA, it is likely to observe the establishment of many FTAs in the near future. Indeed, it may not be unrealistic to imagine the formation of the East Asia FTA, covering all East Asian countries and economies.

In light of strong interest in FTAs by East Asian economies, this paper attempts to examine the impact of East Asia FTA on trade patterns in East Asia by using a multi-sector computable general equilibrium (CGE) model. Since FTA removes tariff and non-tariff barriers on trade among members, East Asia FTA is expected to have substantial impacts on trade patterns of East Asian economies. An analysis of the impacts of an East Asia FTA is useful not only for researchers interested in trade issues, but also for policy makers responsible trade policies.

The structure of the paper is as follows. Section 2 reviews recent developments in

${ }^{1}$ Under the GATT/WTO the term regional trade agreements (RTAs), which include free trade agreement (FTA) and customs union, are used to describe regionalization. But in this paper we use the term FTAs to mean RTAs, as many RTAs, especially those in East Asia, are FTAs. See WTO website, http://www.wto.org for the information on RTAs. 
FTAs in East Asia. Section 3 presents the model and the data used in the simulation analysis. One important objective of this section is to examine trade and protection patterns in East Asia, to set the stage for the simulation analysis of the impact of East Asia FTA on trade in East Asia. Section 4 discusses the results of the simulation. Section 5 concludes the paper.

\section{Emergence of FTAs in East Asia}

East Asia was not active in the formation of regional trade agreements such as free trade agreements (FTAs) until recently ${ }^{2}$. Indeed, ASEAN Free Trade Area (AFTA) was the only major FTA until Japan and Singapore enacted Japan-Singapore FTA (formally Japan-Singapore Economic Partnership Agreement) in November 2002. This section provides a brief discussion on the recent developments concerning FTAs in East Asia.

AFTA was established in 1992 with six ASEAN member countries, Indonesia, Malaysia, the Philippines, Singapore, Thailand, and Brunei. New ASEAN members, Vietnam, Myanmar, Cambodia, and Laos joined AFTA in the latter half of the 1990s, and currently AFTA has 10 member countries. The main objective of AFTA is to develop competitive industries in ASEAN by promoting intra-ASEAN trade. Several factors contributed to the formation of AFTA. One is the realization of the need to capture export market in the face of increasing FTAs in the world. Another factor is the emergence of China as a competitor for attracting FDI. The end of the cold war also had an impact on ASEAN as it made ASEAN concentrate on economic development. Besides AFTA, ASEAN as a group as well as its members have become active in FTA discussions with other countries. One of the FTAs involving ASEAN that has received most attention recently is that with China, which will be discussed below. ASEAN is also discussing the possibility of FTAs with Japan and Korea.

Compared to ASEAN countries in Southeast Asia, the countries in Northeast Asia including China, Japan, and Korea had not been active in FTAs until recently. Despite increasingly strong interest in FTAs by Northeast Asian countries, there is only one FTA (Japan-Singapore FTA) that has been enacted so far. Japan is currently negotiating an FTA with Mexico, and it has been studying possible FTAs with Korea, ASEAN, Thailand, Malaysia, and the Philippines. The importance of FTAs with East Asian countries for Japan and East Asia is understood by many Japanese, including policy makers and business

\footnotetext{
${ }^{2}$ Urata (2002) discusses recent developments on FTAs in East Asia.
} 
people. However, the moves toward the formation of FTAs have been rather weak because of strong opposition from various groups such as non-competitive farmers, who would suffer from trade liberalization of agricultural products.

Korea started having an interest in FTAs before Japan. In 1998 Korea disclosed a plan to start FTA negotiations with Chile, and it also set up a joint-study group at private level on FTA with Japan. Korea started negotiations with Chile in 1999, and Korea and Chile signed the agreement in October 2002 after difficult negotiations on liberalization of agricultural imports. Although the agreement was signed, it has not yet ratified by the Korean National Assembly because of strong opposition from the farmers. Korea also started studying the possible FTA with ASEAN.

China's active FTA strategy has received a lot of attention. China joined the WTO in 2001 and established an access to the world market, and it started to pursue regional strategies by using FTAs. China signed a framework agreement on comprehensive economic cooperation with ASEAN in November 2002. The agreement, which was proposed strongly by China, has not only trade liberalization but also cooperation in the areas of FDI and economic development. China and ASEAN started negotiations on FTA January 2003 with a target for its conclusion by June 2004. China has offered various schemes attractive to ASEAN and particularly to its new members such as economic cooperation for the new ASEAN members and advanced trade liberalization (early harvest) in agricultural products. In addition to ASEAN, China has proposed Japan and Korea to establish a trilateral FTA including these three countries.

An idea of FTA covering East Asian countries has emerged. At the Leaders' summit meeting of ASEAN+3 (China, Japan, and Korea) in 1998 the leaders decided to set up East Asia Vision Group to study long term vision for economic cooperation. The group has presented the leaders with recommendations including the establishment of East Asia FTA. Despite the recommendation from the Vision Group, East Asia FTA has not yet become a concrete agenda at the leaders meeting.

One can think of various factors that have led to an emerging interest in FTAs among the countries in East Asia. Many countries consider FTAs as an effective way to penetrate the market of the member countries. Some countries think FTAs would promote deregulation and structural reform to revitalize their economy. The financial crisis in East Asia increased the awareness of the need for regional cooperation such as FTAs to avoid another crisis and to promote regional economic growth. Rivalry in the region has been a 
factor contributing to an increased interest in FTAs. Specifically, both China and Japan, which are competing to become a 'leader' in the region, are keen on using FTAs to strengthen the relationships with ASEAN and the Newly Industrializing Economies (NIEs). Indeed, in November 2002 Japan proposed an economic partnership framework to ASEAN one day after China agreed to start FTA negotiations with ASEAN. It should also be noted that ASEAN and the NIEs also consider FTAs as a means to maintain and increase their influential position in East Asia.

Currently, the establishment of China-Japan-Korea FTA appears difficult not only because of the opposition groups against trade liberalization but also because of the differences in their views on past history and other non-economic issues. Rather than China-Japan-Korea FTA, the establishment of three ASEAN+1 FTAs, namely ASEAN-China, ASEAN-Japan, and ASEAN-Korea FTAs, may be more likely. Indeed, ASEAN may be interested in establishing three ASEAN+1 FTAs to keep their negotiating position before moving to the establishment of East Asia FTA.

Considering that FTA would contribute to economic growth of the countries involved and considering that FTAs are likely to increase in other parts of the world, it is hoped that East Asia work hard to establish East Asia FTA by overcoming the obstacles with active cooperation. With these observations in mind, we attempt to investigate the likely impacts of the East Asia FTA on East Asian economies in the following sections.

\section{The Impacts of East Asia FTA on East Asian Economies: A Simulation Analysis}

\subsection{The Model}

This section investigates the economic impacts of an East Asia FTA on East Asian economies using the standard Global Trade Analysis Project model (GTAP model) developed by Hertel (1997). ${ }^{3}$ This is a multi-sector, multi-country computable general equilibrium (CGE) model that has been widely used in a number of studies. The characteristics of the GTAP model are summarized as follows. The demand side of the standard GTAP model assumes that total national income is allocated using fixed value shares among three kinds of final demand - government, private household, and savings

3 The impacts of an East Asia FTA using CGE model are also examined in Ballard and Cheong (1997) although they do not focus on the impacts on trade patterns. For more detail, see Ballard and Cheong (1997). 
- which are derived from an aggregate utility function of the Cobb-Douglas form. The single representative household in each country maximizes a constant difference of elasticity expenditure (CDE) function. CDE function is calibrated to different income and the price elasticity of demand, and calibrated elasticity is used to specify private household demand function.

On the production side, the standard GTAP model employs constant returns to scale technology and perfect competition. Production in each sector in each country is represented by a multi-level production function of a Leontief form that involves value-added and intermediate inputs generated from the input-output tables. The demands for factors and intermediate inputs are represented by a nested constant elasticity of substitution (CES) function. Each firm uses a CES composite of domestically produced and imported intermediate goods and determine the optimal mix of imported and domestic goods given domestic and import prices. Imports are distinguished by country of origin (Armington assumption). ${ }^{4}$

Labor is mobile across industries but not across countries. Capital is mobile across industries and countries and its accumulation is endogenously determined. Investments are assembled to be allocated across regions through a hypothetical global sector called the global bank in such a way that the global bank equates the change in the expected rates of return across countries. Transport margins are derived from equating supply and demand in another hypothetical global sector called the global transportation sector. Equilibrium satisfies the conditions in that demand equals supply for all goods and factors, and representative firms in each industry earn zero profit.

\subsection{The Data}

Main data come from the GTAP database Release 5 (GTAP-5), which contains 66 countries/regions and 57 sectors for 1997. ${ }^{5}$ The database provides production and consumption structures described in a social accounting matrix for each country. To facilitate the computation, the database is aggregated into 20 countries and 21 sectors.

In the GTAP database, trade barriers, which include tariff- and non-tariff measures, are described as the differences between domestic market prices and world market prices.

\footnotetext{
4 For more detail about current standard GTAP model, see http://www.gtap.agecon.purdue.edu/products/models/current.asp.

5 For the GTAP-5, see Dimaranan and McDougal (2002).
} 
Thus, the tariff and non-tariff measures cover import tariffs, export subsidies, and domestic supports (output subsidies, intermediate input subsidies, land-based payments, and capital-based payments). ${ }^{6}$ However, the information on the barriers in service trade is still under development and does not cover many barriers. ${ }^{7}$ Hence, this paper focuses on merchandise trade, that is, agricultural, mining and manufacturing trade in analyzing trade flows.

\subsubsection{Trade Patterns of East Asian Economies}

Table 1 summarizes the export and import compositions of East Asian economies in 1997 from GTAP-5. Three distinct features are observed in this table. First, major exports of many East Asian economies are textile and machinery, especially electric equipments. Second, major imports of many East Asian economies are concentrated in electric equipments and general machinery. Third, the shares of imports for agriculture, and food products and beverages are larger than the corresponding export shares for all the economies except for Vietnam. However, we should also note that most East Asian economies show low compositional shares in trade (exports and imports) for agriculture and food products and beverages except for Thailand and Vietnam for exports and Japan for imports.

\section{$===$ Table $1===$}

Table 2 presents the intra-industry trade (IIT) patterns and revealed comparative advantage (RCA) for East Asian economies ${ }^{8}$. The IIT index takes the value between 0 and 100 , and it increases with the extent of intra-industry trade. RCA takes the value greater than or equal to zero. If RCA for an industry for a country takes the value greater than unity, it is interpreted that the country has a comparative advantage in that industry. Similarly, if it takes the value less than unity, then the industry has a comparative disadvantage.

${ }^{6}$ In GTAP-5, zero rates are reported for anti-dumping duties, price undertakings and voluntary export restraints (VERs) due to the absence of up-to-date data (Dimaranan (2002, p.16-A-11)).

${ }^{7}$ Because of the limited data availability, the number of sectors significantly decreases when we include the trade barriers in services in the CGE analysis. For a study that focuses on the trade barriers in services, see Brown and Stern (2001).

${ }^{8}$ For the formulas used to compute the IIT index and RCA index, see Appendix. 
There are three notable findings in this table. First, for many economies, pulp, chemicals, and electronic equipment tend to show large figures for the IIT index. Second, most of agriculture, forestry, fishing, mining and food products and beverages do not register large ITT figures. Third, the largest RCA is likely to be observed in electric equipment. Specifically, electric equipment presents largest RCA figures for Japan, Korea, Singapore, Taiwan, the Philippines and Thailand. The large numbers also appear in textiles and fishing. It is interesting to note that transportation machinery takes values greater than unity only for Japan and Korea, while general machinery takes values greater than unity only for Japan and Taiwan.

These observations indicate that many East Asian economies have a comparative advantage in the production of electric equipment, and many economies appear to engage in vertical division of labor in electronic equipment production. Specifically, many East Asian economies' competitiveness comes from labor-intensive assembling operation in the production of electronic equipment, as they import electronic parts and components to assemble finish products and export them to foreign countries.

Table 3 presents the three types of regionalization measures in terms of trade for East Asian economies ${ }^{9}$. The absolute measure compares the scale of a particular intra-regional trade relationship to world trade, while the relative measure compares it to its overall regional trade. The double relative measure, which is commonly called the trade intensity index, shows the intensity or bias of the intra-regional trade relationship by taking into account its importance in world trade. The value of unity for the double relative measure can be interpreted so that the intra-regional trade relationship is neutral, while the relationship is more (or less) biased when the measure is greater (or less) than unity.

The computed absolute measures show that intra-regional trade in East Asia and ASEAN amount to 11 and 1 percent of world trade, respectively. As to the relative measures, the share of intra-regional exports in East Asia's exports was 44 percent, while the share of intra-regional imports in East Asia's imports was larger at 50 percent. These

9 The definitions of the three measures are given in Appendix. See Petri (1993) and Urata (2001) for the discussion of the regionalization measures and their application to East Asian economies. 
findings on the relative measures for exports and imports indicate that East Asia is an important source of imports rather than a destination of exports. The relative measures for exports and imports for ASEAN are 21 and 20 percent, respectively, significantly smaller compared with trade in East Asia. ASEAN countries depend on non-ASEAN countries, particularly other East Asian countries, in their trade. The computed double-relative measures show that trade in both East Asia and ASEAN have strong intra-regional bias. Intra-regional bias is particularly strong for ASEAN trade, reflecting the presence of the AFTA, under which preferential treatment is given to intra-ASEAN trade.

\section{$===$ Table $3===$}

The results for disaggregated sector levels reveal several interesting developments. First, for electronic equipment, fishing, and textiles intra-regional trade in East Asia has a significant share in world trade, indicating that these products are actively traded in the region. Second, for electronic equipment and textiles, East Asia is an important source of imports rather than a destination of exports, reflecting the pattern of production and trade, in which parts and components are procured in East Asia to be assembled for the finished products in East Asia, which in turn are exported to outside the region. Third, high double relative measures are observed for ASEAN trade vis-à-vis East Asia trade for all products except mining, indicating the influence of the AFTA on trade in a wide range of products.

\subsubsection{Nominal and Effective Rate of Protection for East Asian Economies}

In the GTAP database, trade barriers, which include tariff- and non-tariff measures, can be expressed as the differences of prices between domestic market prices and world market prices. We denote the difference as the nominal rate of protection (NRP). We also compute the effective rate of protection (ERP), which accounts for the protection on value added by taking into account of protection given not only to the product under study but also to intermediate inputs used for the product. ${ }^{10}$

Table 4 presents the calculated results of NRPs and ERPs from the GTAP database. There are three notable findings in this table. First, for China, Japan and Korea, the levels of protection on agriculture and food products and beverages are extremely high. NRPs on food products and beverages are also high for these three countries and Taiwan. The results

10 Appendix explains the computational method of ERP. 
for China are somewhat surprising, as China exports substantial magnitudes of agricultural products, food products and beverages.

\section{$===$ Table $4==$}

Similarly, ERPs tend to high for these industries in these countries with few exceptions, indicating that these industries are given substantial protection from import competition. Two exceptions are agriculture in Taiwan and food products and beverages in Korea, for which negative ERPs are obtained. These negative results are due to the fact that NRPs given to intermediate goods for the production of agriculture (in the case of Taiwan) and food products and beverages (in the case of Korea) are higher than NRPs given to agriculture, and food products and beverages. In other words, agriculture in Taiwan and food products and beverages in Korea suffer from negative discrimination imposed by their governments.

Second, high level of protection is given in paper, chemicals and machinery industries in ASEAN countries as well as China, and these industries tend to present larger figures for ERP than for NRP. Such patterns of protection, that is, higher ERP than NRPs, are common in many countries and characterized as tariff escalation. Indeed, tariff escalation is regarded as rational patterns of tariff protection for the development of a particular industry, although the effectiveness of such policy appears questionable. It is to be noted that high protection is observed for transportation machinery industry in many ASEAN countries and China, reflecting the importance of the industry for these governments.

Third, there are virtually almost no trade barriers in Hong Kong and Singapore. Only agriculture and food products and beverages receive protection, although the level of protection given to this industry by these governments is substantially low when compared to the cases for other East Asian economies.

\section{Simulation Results}

We conducted a simulation analysis to discern the impacts of an East Asia FTA by removing trade barriers among East Asian economies. In this section we examine the results. We begin with the results for GDP and economic welfare in terms of equivalent 
variation (EV), and then turn to the results on overall as well as sectoral outputs and trade.

Table 5 presents simulation results for GDP and EV for East Asian economies with a few selected countries. The results indicate that all FTA member economies obtain benefits from an East Asia FTA in terms of GDP and EV. The positive impacts are very large for the ASEAN countries. Among the ASEAN countries Thailand gains substantially. Indeed, Thai GDP is estimated to increase as much as 16 percent from an East Asia FTA. Large gain for Thailand is attributable mainly to high protection imposed on the Thai economy before East Asia FTA. Vietnam and Indonesia also would gain substantially from an East Asia FTA.

By contrast to the gains accrued to the FTA members, non-member countries experience negative impacts in the forms of declines in GDP and EV. These negative impacts are mainly attributable to the trade diversion effect from the East Asia FTA, by which non-member countries' exports to East Asia are substituted by member countries' exports as a result of preferential treatment given to trade between the members. It should be noted that the negative impacts on the United States and the EU are quite small while they are somewhat substantial for Australia/New Zealand and other Asia. Relatively large negative impacts for Australia/New Zealand and other Asia stem from the fact that East Asia is a very important region for their export destination. Since the results of the simulation depend on the elasticity of substation between domestic and imported products, we examine how sensitive our results are to the size of elasticity by conducting a simulation with 10 percent increase in the elasticity values. We found that the results are greater by approximately 10 percent, indicating the importance of the size of elasticities in determining the impacts of FTA $^{11}$.

$===$ Table $5===$

The impacts of an East Asia FTA on the changes in real outputs and real exports in agriculture and manufacturing sectors are presented in Table 6. For Hong Kong, Singapore, Indonesia, Malaysia, the Philippines and Thailand, positive impacts on real outputs are observed in almost all industries. One major exceptional sector is transportation machinery, whose production declines for these economies except for the Philippines. Indeed, it should be noted that production of transportation machinery declines for all the economies except

${ }^{11}$ The results are not given in the paper, but they are available on request from the authors. 
Japan and the Philippines. Unlike the case for many economies noted above, China, Japan, Korea, and Taiwan show sectoral variations in the direction of the changes in output.

Notable increases in output production are observed for the following sectors for the East Asian economies; agriculture (China, Singapore, and Thailand), food products and beverages (Korea, Hong Kong, Singapore, Malaysia, and Thailand), textiles (Korea, Taiwan, Philippines, and Vietnam), electronic equipment (China, Indonesia, Philippines, and Thailand), and general machinery (Indonesia, Philippines, and Thailand). Some notable declines in output production are recorded as follows; agriculture (Japan and Korea), iron and steel (Vietnam), and transportation machinery (China, Singapore, Indonesia, Malaysia, Thailand, and Vietnam). These findings reveal the difficulty in establishing an East Asia FTA because of its negative impacts on the sectors with political influence in respective economies.

\section{$===$ Table $6==$}

We have examined the impacts of an East Asia FTA on output at sectoral level and found variations in its impacts among the sectors. It is of interest to examine if any systematic patterns exist in explaining the impact of an East Asia FTA among different sectors and economies. One would expect that output of the sector that has a comparative advantage would increase more compared to that of the sectors with comparative disadvantage as a result of FTA, because freer trade environment would give greater opportunities for output expansion for the sectors with comparative advantage. Along the similar line of the argument one would expect that output of the protected sector would decline as a result FTA because of increased import competition. We examined these hypotheses by conducting regression analysis covering 11 economies and 13 sectors. For the analysis three different models are examined. The dependent variable, which is the same for the three models, is the rate of change in output, and explanatory variables are RCA, NRP, and ERP at base year, respectively. The results of the analysis support the first hypothesis, indicating that FTA increase output of the sectors with comparative advantage (Table 7). However, they do not support the second hypothesis.

$===$ Table $7===$ 
It is interesting to observe that exports increase for all the economies for almost all products with a few exceptions. Even exports of transportation machinery, whose production is shown to decline, are expected to increase for all the economies except for Hong Kong and Singapore. These contrasting patterns of change in production and exports in transportation machinery reflect increased incentive given to exportation as a result of elimination of protection under the East Asia FTA. The sectors with substantial increase in exports include the following: agriculture (China, Japan, Korea, Singapore, and the Philippines), food products and beverages (all economies), textiles (Japan, Korea, and Vietnam), transport machinery (Indonesia, Malaysia, the Philippines, Thailand, and Vietnam), electronic equipment (China, Indonesia, and Thailand), and general machinery (Indonesia and Thailand). One should note that these values are the rate of change, as such a large value may be partly due to the low initial value before the formation of an East Asia FTA. A case in point is agriculture and food products and beverages for Japan, for which large rates of export growth are expected partly because of low export value before the formation of an East Asia FTA.

Following the discussions on the determinants of the change in output above, we examine the determinants of the change in exports using the same framework. One would expect the sectors with a comparative advantage and the sectors with low protection to increase as a result of an East Asia FTA. The results show that exports of the sectors with high protection increase as a result of East Asia FTA. This unexpected result can be explained by a shift of incentives from domestic sales to export sales because of the removal of protection. As to the relationship between RCA and export expansion, we could not detect the expected relationship.

The impacts of an East Asia FTA on export change lead to the changes in the composition of exports, which are shown in Table 8. The figures for 1997 indicate the export composition in 1997 (obtained from Table 1) and those under FTA indicate the export composition after the simulation. Italic figures indicate the percentage changes between compositions in 1997 and those in FTA.

\section{$===$ Table $8===$}

The results show that the impacts of East Asia FTA are not large enough to change 
the composition of each economy's exports and imports substantially ${ }^{12}$. Specifically, the changes in exports with more than 5.0 percentage points are confirmed for only a few sectors such as mining in Vietnam, food products and beverages in Korea and Thailand and textiles in Vietnam. For other sectors and economies, the magnitudes of the changes are less than 5.0 percentage points, most of which are less than 1.0 percentage point.

An analysis of the impacts of an East Asia FTA on intra-industry trade pattern is of interest. One would argue that FTA may expand intra-industry trade because enlarged regional market resulting from the elimination of trade barriers gives greater trade opportunities for differentiated products. However, the results shown in Table 9 do not support this argument, as more than a half cases, specifically 73 cases out of 143 cases (11 economies and 13 sectors), show a minus sign, reflecting the decline in the intra-industry trade.

\section{$===$ Table $9==$}

We now turn to the impacts of an East Asia FTA on regional trading patterns. Table 10 presents the regionalization indexes for East Asia and ASEAN countries. The results indicate that for overall trade all three regionalization measures increase for East Asia as a result of an East Asia FTA. These observations, which appear to reflect that the trade diversion effect is greater than the trade creation effect, indicate that the establishment of the FTA promotes regionalization. This result is consistent with our expectation because FTA is trade arrangement, which treat the members preferentially and non-members discriminatorily. Contrary to the case for East Asia as a whole, intra-regional trade bias declines for ASEAN, although the absolute and relative measures of regionalization increase. This finding indicates that for ASEAN extra-ASEAN trade expands faster than intra-ASEAN trade.

\section{$===$ Table $10===$}

\footnotetext{
12 It should be added that an East Asia FTA does not change the patterns of revealed comparative advantage (RCA) significantly, as can be expected from small changes in the compositions of exports. The RCA figures under an East Asia FTA are available from the authors on request.
} 
At the sector-level, for almost all sectors absolute and relative measures increase as a result of an East Asia FTA. This means that the importance of intra-regional trade in East Asia and AFTA countries increase with respect to the world trade as well as their own trade. The rates of change are particularly high for agriculture, food products and beverages, and transportation machinery for East Asia. Unlike the patterns observed for the absolute and relative measures, the rates of change for the double relative measure are not uniform. For East Asian trade, large increases in regional bias are observed for agriculture, pulp, paper, and paper products, and general machinery, while notable decline is observed for chemicals. For ASEAN many products show a decline in a bias with notable exceptions for agriculture and general machinery. These results imply that an East Asia FTA promotes the regionalization within East Asia, and it encourages ASEAN countries to have closer relationship with other East Asian economies.

\section{Conclusions}

In light of increasingly strong interest in FTAs and an East Asia FTA among many East Asian economies, we investigated the economic impacts of an East Asia FTA on East Asian economies with a focus on trade patterns by conducting a simulation analysis utilizing a computable general equilibrium model. We found that an East Asia FTA brings positive impacts to East Asian economies in terms of economic growth and economic welfare. As to its impacts on trade patterns for East Asian economies, the simulation results show relatively small impacts but they reveal some interesting patterns. We found that the sectors with a comparative advantage increase output and those with strong protection increase exports. The former relationship is expected but the latter finding is not consistent with the expectation. One explanation for this unexpected result is that an FTA shifts an incentive from domestic sales to export sales for protected sectors. Although exports of many sectors would increase as a result of an East Asia FTA, output production of some sectors is likely to decline. These potentially impacted sectors do oppose an East Asia FTA. To overcome such opposition and to establish an East Asia FTA, financial and technical assistance should be given to potentially impacted workers to ameliorate the costs of adjustment. An East Asia FTA is found to promote regionalization in trade in East Asia, partly at the cost of exports from outside the region. Indeed, it has negative impacts in terms of economic growth and welfare on non-members. These findings argue strongly the 
need to pursue worldwide trade liberalization under the WTO. Indeed, the formation of an East Asia FTA has to be regarded as a step toward multilateral liberalization.

We have examined the impacts of an East Asia FTA on trade patterns in East Asia by using a CGE model. Our results present useful information on the likely impacts of such FTA. However, we do realize some shortcomings. First, there are some features of FTAs that could not be incorporated satisfactorily in our model, and we need to devise the ways to incorporate them more satisfactorily. They include rules of origin, foreign direct investment (FDI), technology transfer associated with FDI, international labor mobility and others. Besides the issues related to the simulation model, which is constructed at the sector level, we also realize the need to investigate the likely impacts of FTAs at firm level, to discern the detailed impacts of FTAs. As the availability of firm-level data has become better in recent years, researchers should analyze the impacts of trade liberalization on firms' trading behavior, to draw some implications on the impacts of FTAs. Finally we strongly hope that our results will be used for policy discussions on an East Asia FTA.

\section{References}

Ballard, Charles L. and Inkyo Cheong. 1997. "The Effects of Economic Integration in the Pacific Rim: A Computational General Equilibrium Analysis," Journal of Asian Economics, 8(4): 505-524.

Brown, Drusilla K. and Robert M. Stern. 2001. "Measurement and Modeling of the Economic Effects of Trade and Investment Barriers in Services," Review of International Economics, 9(2): 262-286.

Dimaranan, Betina V. 2002. "Construction of the Protection Data Base," in Dimaranan, Betina V. and Robert A. McDougall. (eds.), 2002. Global Trade, Assistance, and Production: The GTAP 5 Data Base, Westlafayette: Center for Global Trade Analysis, Department of Agricultural Economics, Purdue University.

Dimaranan, Betina V. and Robert A. McDougall. (eds.), 2002. The GTAP 5 Data Base, West

Lafayette, IN: Center for Global Trade Analysis, Department of Agricultural Economics, Purdue University.

Hertel, Thomas W. (ed.), 1997. Global Trade Analysis: Modeling and Applications, Cambridge, UK: Cambridge University Press.

Petri, Peter A. 1993. "The East Asian Trading Bloc: An Analytical History,” Jefferey A. 
Frankel and Miles Kahler. (eds.), Regionalism and Rivalry: Japan and the United States in Pacific Asia, Chicago: University of Chicago Press.

Urata, Shujiro. 2001. "Emergence of an FDI-Trade Nexus and Economic Growth in East Asia," Joseph Stiglitz and Shahid Yusuf. (eds.), Rethinking the East Asian Miracle, New York, Oxford University Press.

Urata, Shujiro. 2002. "A Shift from Market-led to Institution-led Regional Economic Integration in East Asia," paper presented at the RIETI international conference, 'Asian Economic Integration,' April, Tokyo, Japan.

\section{Appendix. Definitions of Variables}

$\underline{\text { Regionalization index }}$

We use three types of regionalization index. First index is called absolute measure and defined as:

$$
A=\frac{x_{j k}}{\sum_{k} \sum_{j} x_{j k}}
$$

where $j$ and $k$ indicate home and partner countries, respectively. $x_{j k}$ represents exports from country $j$ to country $k$, respectively. Therefore, absolute measure captures export the share of country $j$ to country $k$ relative to world total exports.

Second index is called relative measure, which is defined as:

$$
B=\frac{A}{\sum_{k} x_{j k} / \sum_{k} \sum_{j} x_{j k}}=\frac{x_{j k}}{\sum_{k} x_{j k}} .
$$

The relative measure indicates the export share of country $j$ to country $k$ relative to country $j$ 's total exports.

Third index is called double relative measure. Double relative measure is the divided by home and partner export shares so that we could partly control both home and partner's scale.

$$
C=\frac{A}{\left(\sum_{k} x_{j k} / \sum_{k} \sum_{j} x_{j k}\right)\left(\sum_{j} x_{j k} / \sum_{k} \sum_{j} x_{j k}\right)}=\frac{x_{j k} \times \sum_{k} \sum_{j} x_{j k}}{\sum_{j} x_{j k} \times \sum_{k} x_{j k}},
$$


The value of exports is evaluated at the domestic market price while value of imports is evaluated at the world price.

$\underline{\text { Intra-Industry Trade (IIT) index }}$

Intra-industry index is defined as:

$I I T_{i j}=\left(1-\frac{\sum_{k}\left|x_{i j k}-m_{i j k}\right|}{\sum_{k}\left(x_{i j k}+m_{i j k}\right)}\right) \times 100$,

where $i, j$ and $k$ indicate industry, home country and partner country, respectively. $x_{i j k}$ and $m_{i j k}$ represent exports and imports of industry $i$ in country $j$ to country $k$, respectively. IIT index takes value between 0 and 100. The larger the index is, the larger the intra-industry trade will be. The value of exports is evaluated at the domestic market price while the value of imports is evaluated at the world price.

Note that the definition of IIT index in GTAP model is different from that of Grubel=Lloyd type IIT index. The former is differentiated across countries in the same industry. The latter is differentiated across sub-industries (or detailed level of industries) in the same industry.

$\underline{\text { Revealed Comparative Advantage (RCA) }}$

RCA is defined as:

$R C A_{i j}=\frac{x_{i j} / \sum_{i} x_{i j}}{\sum_{j} x_{i j} / \sum_{j} \sum_{i} x_{i j}}$,

where $i$ and $j$ indicate industry and home country, respectively. $x_{i j}$ represents exports of industry $i$ in country $j$ to world and evaluated at domestic market price. Therefore, $R C A_{i j}>1$ means that industry $i$ in country $j$ has comparative advantage (compared with world average) while $R C A_{i j}<1$ means $i$ in country $j$ has comparative disadvantage. 


\section{Nominal Rate of Protection (NRP)}

The rate of protection in imports is defined as:

$t_{i j}=\left(m_{i j}^{M}-m_{i j}^{W}\right) / m_{i j}^{W}$,

where $i$ and $j$ indicate industry and home country. $m_{i j}^{M}$ and $m_{i j}^{W}$ are the values of imports evaluated at the domestic market price and at the world price, respectively. Hence, the rate of protection in imports includes both tariff barriers and non-tariff measures.

\section{Effective Rate of Protection (ERP)}

We define Effective Rate of Protection (ERP) as follows.

$E R P_{i j}=\frac{t_{i j}-\sum_{z} t_{m j} a_{i z j}}{1-\sum_{z} a_{i z j}}$,

where $i, z$ and $j$ indicate final goods industry, intermediate goods industry and home country, respectively. $a_{i z j}$ indicate the input coefficient from industry $i$ to $m$ in country $j$ obtained from input-output table in GTAP database. $t_{i j}$ is the NRP defined as above. The rate of protection in this analysis, therefore, includes both tariff and non-tariff barriers. 
Table 1. Export and Import Compositions of East Asian Economies in 1997 (percentage shares in total)

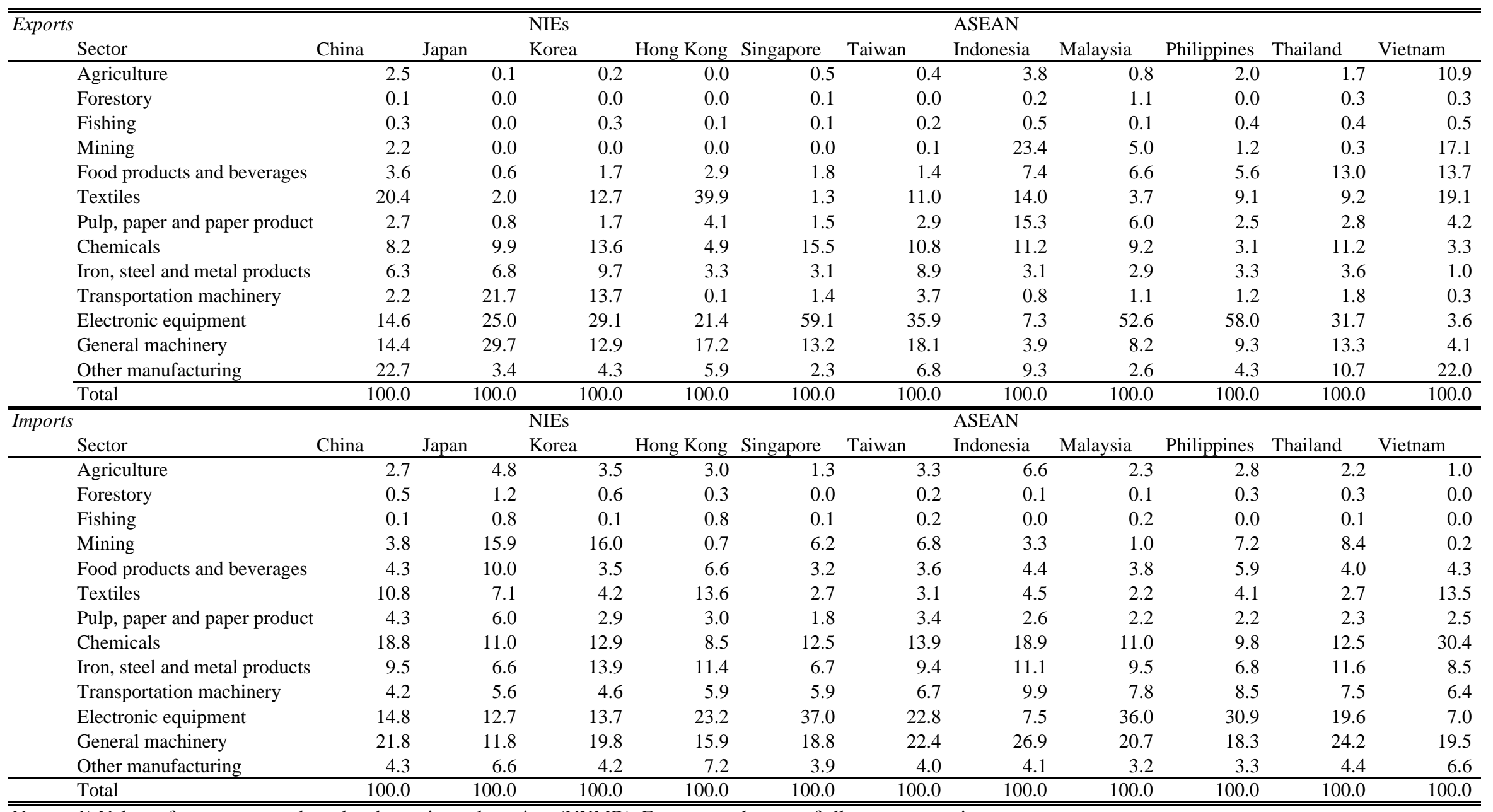

Notes: 1) Values of exports are evaluated at domestic market prices (VXMD). Exports are the sum of all partner countries.

2) Values of imports are evaluated at world prices (VIWS). Imports are the sum of partner countries.

3) Total excludes the services sectors.

Source: GTAP Version 5. 
Table 2. Intra-Industry Trade (IIT) Patterns and Revealed Comparative Advantage of East Asian Economies in 1997

\begin{tabular}{|c|c|c|c|c|c|c|c|c|c|c|c|}
\hline Intra-Industry Trade (IIT) Index & & \multirow[b]{2}{*}{ Japan } & \multicolumn{3}{|l|}{ NIEs } & \multicolumn{3}{|c|}{ ASEAN } & \multirow[b]{2}{*}{ Philippines } & \multirow[b]{2}{*}{ Thailand } & \multirow[b]{2}{*}{ Vietnam } \\
\hline 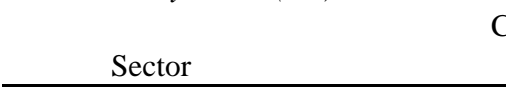 & China & & Korea & Hong Kong & Singapore & Taiwan & Indonesia & Malaysia & & & \\
\hline Agriculture & 34.5 & 4.2 & 6.3 & 0.9 & 32.9 & 14.1 & 40.6 & 21.2 & 26.9 & 38.6 & 17.6 \\
\hline Forestory & 9.3 & 1.4 & 1.5 & 0.3 & 40.2 & 8.2 & 36.6 & 5.5 & 12.0 & 15.2 & 21.0 \\
\hline Fishing & 24.5 & 7.4 & 23.5 & 4.9 & 24.9 & 13.3 & 5.7 & 14.7 & 11.0 & 13.6 & 19.9 \\
\hline Mining & 13.5 & 0.7 & 0.5 & 0.2 & 0.9 & 1.5 & 10.8 & 14.7 & 2.3 & 2.8 & 2.7 \\
\hline Food products and beverages & 36.5 & 14.0 & 32.8 & 23.5 & 51.0 & 39.6 & 40.7 & 43.8 & 48.0 & 36.9 & 43.9 \\
\hline Textiles & 38.7 & 50.8 & 50.9 & 43.3 & 46.0 & 35.2 & 27.6 & 52.5 & 26.5 & 32.6 & 31.9 \\
\hline Pulp, paper and paper product & 65.6 & 26.5 & 35.8 & 52.8 & 60.0 & 60.4 & 22.5 & 42.8 & 69.1 & 61.8 & 49.2 \\
\hline Chemicals & 56.9 & 73.0 & 54.4 & 21.1 & 56.2 & 46.9 & 63.1 & 78.8 & 28.8 & 69.5 & 13.9 \\
\hline Iron, steel and metal products & 60.3 & 56.7 & 51.7 & 15.7 & 42.8 & 51.9 & 43.8 & 48.0 & 47.8 & 42.2 & 14.4 \\
\hline Transportation machinery & 42.1 & 32.6 & 40.7 & 1.4 & 21.9 & 55.0 & 13.7 & 22.0 & 16.0 & 21.4 & 4.9 \\
\hline Electronic equipment & 53.2 & 55.8 & 57.8 & 30.8 & 65.8 & 52.1 & 62.3 & 66.0 & 67.8 & 69.3 & 22.9 \\
\hline General machinery & 58.5 & 46.3 & 43.9 & 29.7 & 49.0 & 57.7 & 26.0 & 55.0 & 47.6 & 56.7 & 17.2 \\
\hline Other manufacturing & 22.0 & 67.1 & 78.7 & 36.9 & 43.5 & 59.1 & 36.6 & 64.6 & 46.9 & 53.8 & 23.1 \\
\hline Reveald Comparative Advantage (RCA) & & & NIEs & & & & ASEAN & & & & \\
\hline Contar C & China & Japan & Korea & Hong Kong & Singapore & Taiwan & Indonesia & Malaysia & Philippines & Thailand & Vietnam \\
\hline Agriculture & 0.88 & 0.03 & 0.06 & 0.01 & 0.15 & 0.13 & 1.28 & 0.27 & 0.50 & 0.51 & 3.71 \\
\hline Forestory & 0.33 & 0.03 & 0.03 & 0.00 & 0.45 & 0.09 & 0.82 & 5.78 & 0.13 & 1.51 & 1.39 \\
\hline Fishing & 1.63 & 0.13 & 1.51 & 0.47 & 0.48 & 1.08 & 2.73 & 0.61 & 1.59 & 2.12 & 2.95 \\
\hline Mining & 0.37 & 0.01 & 0.01 & 0.00 & 0.01 & 0.01 & 3.81 & 0.81 & 0.14 & 0.05 & 2.84 \\
\hline Food products and beverages & 0.68 & 0.12 & 0.31 & 0.30 & 0.30 & 0.26 & 1.36 & 1.18 & 0.76 & 2.19 & 2.56 \\
\hline Textiles & 3.53 & 0.33 & 2.13 & 3.75 & 0.19 & 1.92 & 2.34 & 0.60 & 1.13 & 1.40 & 3.24 \\
\hline Pulp, paper and paper product & 0.64 & 0.17 & 0.38 & 0.52 & 0.30 & 0.67 & 3.45 & 1.33 & 0.41 & 0.58 & 0.98 \\
\hline Chemicals & 0.67 & 0.77 & 1.07 & 0.22 & 1.10 & 0.88 & 0.88 & 0.71 & 0.18 & 0.81 & 0.26 \\
\hline Iron, steel and metal products & 0.86 & 0.88 & 1.28 & 0.24 & 0.37 & 1.22 & 0.41 & 0.38 & 0.33 & 0.43 & 0.13 \\
\hline Transportation machinery & 0.20 & 1.91 & 1.23 & 0.01 & 0.12 & 0.35 & 0.07 & 0.10 & 0.08 & 0.14 & 0.02 \\
\hline Electronic equipment & 1.17 & 1.91 & 2.26 & 0.94 & 4.14 & 2.90 & 0.57 & 4.00 & 3.33 & 2.26 & 0.28 \\
\hline General machinery & 0.86 & 1.69 & 0.74 & 0.56 & 0.69 & 1.09 & 0.23 & 0.46 & 0.40 & 0.70 & 0.24 \\
\hline Other manufacturing & 4.00 & 0.57 & 0.73 & 0.56 & 0.36 & 1.20 & 1.58 & 0.43 & 0.54 & 1.67 & 3.81 \\
\hline
\end{tabular}

Note: For definition of IIT index and RCA, see Appendix in the main text.

Source: GTAP Version 5. 
Table 3. Regionalization in Trade for East Asian Economies in 1997

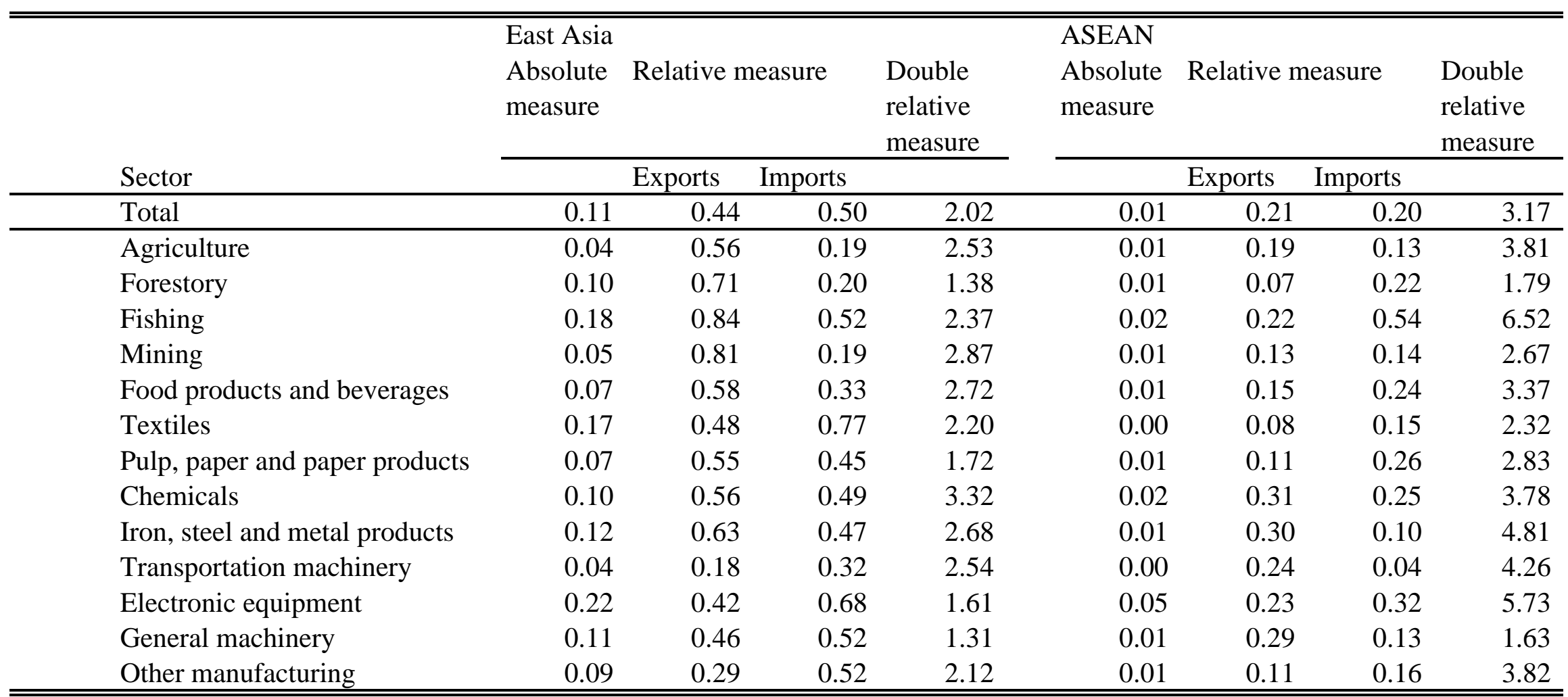

Notes: 1) East Asia is all the countries listed in Table 1 (or Table 2) while ASEAN is Indonesia, Malaysia, Philippines, Singapore, Thailand and Vietnam.

2) For definition of each measure, see Appendix in the main text.

Source: GTAP Version 5. 
Table 4. Nominal and Effective Rate of Protection of East Asian Economies in 1997

\begin{tabular}{|c|c|c|c|c|c|c|c|c|c|c|c|}
\hline \multicolumn{3}{|c|}{ Nominal Rate of Protection (NRP) in $1997(\%)$} & \multicolumn{4}{|l|}{ "NIEs } & \multicolumn{5}{|l|}{ ASEAN } \\
\hline Sector & China & Japan & Korea & Hong Kong & Singapore & Taiwan & Indonesia & Malaysia & Philippines & Thailand & Vietnam \\
\hline Agriculture & 41.3 & 58.4 & 110.9 & 0.0 & 3.5 & 6.0 & 5.2 & 31.1 & 15.0 & 20.3 & 13.6 \\
\hline Forestory & 2.6 & 0.2 & 2.0 & 0.0 & 0.0 & 0.4 & 1.1 & 0.0 & 0.5 & 1.5 & 3.3 \\
\hline Fishing & 14.2 & 4.9 & 15.8 & 0.0 & 0.0 & 31.1 & 7.5 & 1.4 & 6.6 & 44.9 & 8.9 \\
\hline Mining & 0.2 & -1.4 & 3.9 & 0.0 & 0.0 & 4.9 & 2.8 & 1.1 & 1.0 & 0.3 & 3.2 \\
\hline Food products and beverages & 37.4 & 50.0 & 37.7 & 0.0 & 4.6 & 26.1 & 14.8 & 14.8 & 18.7 & 37.2 & 36.5 \\
\hline Textiles & 25.7 & 10.7 & 8.0 & 0.0 & 0.0 & 8.1 & 15.6 & 16.1 & 13.6 & 26.7 & 34.0 \\
\hline Pulp, paper and paper product & 11.7 & 2.2 & 5.3 & 0.0 & 0.0 & 2.9 & 6.2 & 9.1 & 11.4 & 12.6 & 19.1 \\
\hline Chemicals & 12.6 & 2.3 & 7.0 & 0.0 & 0.0 & 3.7 & 7.1 & 8.6 & 6.4 & 15.3 & 16.1 \\
\hline Iron, steel and metal products & 9.7 & 1.0 & 4.9 & 0.0 & 0.0 & 4.0 & 8.1 & 6.1 & 8.1 & 11.9 & 8.1 \\
\hline Transportation machinery & 18.9 & 0.0 & 4.6 & 0.0 & 0.0 & 13.2 & 25.4 & 19.7 & 10.3 & 31.5 & 36.9 \\
\hline Electronic equipment & 11.9 & 0.0 & 8.0 & 0.0 & 0.0 & 2.9 & 8.1 & 0.8 & 3.1 & 8.8 & 9.7 \\
\hline General machinery & 13.5 & 0.3 & 7.8 & 0.0 & 0.0 & 4.9 & 3.9 & 5.1 & 5.5 & 10.4 & 6.7 \\
\hline Other manufacturing & 16.9 & 5.5 & 7.3 & 0.0 & 0.0 & 5.6 & 9.5 & 8.2 & 12.0 & 13.2 & 16.9 \\
\hline \multicolumn{12}{|c|}{ Effective Rate of Protection (ERP) in 1997 (\%) } \\
\hline Sector & China & Japan & Korea & Hong Kong & Singapore & Taiwan & Indonesia & Malaysia & Philippines & Thailand & Vietnam \\
\hline Agriculture & 51.6 & 84.2 & 154.2 & 0.0 & 4.3 & -0.5 & 5.1 & 37.3 & 16.2 & 20.6 & 14.7 \\
\hline Forestory & 0.6 & -1.8 & 0.9 & 0.0 & -0.1 & 0.3 & 0.5 & -0.2 & -0.2 & 1.3 & 3.1 \\
\hline Fishing & 9.5 & 2.4 & 21.5 & 0.0 & 0.0 & 40.2 & 8.2 & 1.1 & 6.6 & 54.3 & 10.0 \\
\hline Mining & -5.4 & -3.3 & 4.6 & 0.0 & 0.0 & 5.5 & 2.7 & 1.1 & 0.1 & -0.1 & 3.6 \\
\hline Food products and beverages & 60.5 & 104.7 & -57.6 & 0.0 & 8.2 & 90.6 & 30.1 & -15.4 & 29.2 & 71.2 & 133.9 \\
\hline Textiles & 33.2 & 19.3 & 12.9 & 0.0 & 0.0 & 16.1 & 22.6 & 26.7 & 18.7 & 37.1 & 83.6 \\
\hline Pulp, paper and paper product & 10.6 & 3.5 & 7.7 & 0.0 & 0.0 & 4.5 & 12.0 & 19.6 & 24.1 & 15.4 & 60.8 \\
\hline Chemicals & 22.2 & 3.8 & 9.4 & 0.0 & 0.0 & 5.6 & 11.6 & -1.0 & 4.6 & 17.8 & 58.1 \\
\hline Iron, steel and metal products & 17.5 & 1.5 & 7.2 & 0.0 & 0.0 & 7.0 & 11.8 & 10.2 & 16.6 & 14.0 & 15.1 \\
\hline Transportation machinery & 36.0 & -1.1 & 4.8 & 0.0 & 0.0 & 30.9 & 35.7 & 27.8 & 18.5 & 37.9 & 156.8 \\
\hline Electronic equipment & 14.7 & -0.8 & 16.3 & 0.0 & 0.0 & 3.9 & 9.1 & -2.4 & 1.4 & 9.2 & 19.8 \\
\hline General machinery & 21.3 & -0.1 & 11.7 & 0.0 & 0.0 & 8.7 & 1.7 & 6.5 & 6.2 & 11.2 & 19.9 \\
\hline Other manufacturing & 24.6 & 10.8 & 11.2 & 0.0 & 0.0 & 11.5 & 10.6 & 12.4 & 18.8 & 15.2 & 34.0 \\
\hline
\end{tabular}

Note: For the definition of NRP and ERP, see Appendix in the main text.

Source: GTAP Version 5. 
Table 5. Estimated Effects of an East Asia FTA on Real GDP and Equivalent Variation, for Slected Countries/Regions

\begin{tabular}{|c|c|c|c|}
\hline & $\begin{array}{l}\text { GDP } \\
\text { (Changes from } \\
\text { basedata, \%) }\end{array}$ & $\begin{array}{l}\text { Equivalent Variation } \\
\text { (Changes from } \\
\text { basedata, US\$ } \\
\text { million) }\end{array}$ & $\begin{array}{l}\text { (Changes } \\
\text { divided by } \\
\text { GDP in } 1997,\end{array}$ \\
\hline Australia/New Zealand & -0.23 & $-1,342$ & -0.29 \\
\hline China & 1.27 & 5,485 & 0.64 \\
\hline Hong Kong & 1.41 & 3,389 & 2.42 \\
\hline Japan & 0.05 & 8,199 & 0.19 \\
\hline Korea & 1.71 & 7,805 & 1.75 \\
\hline Taiwan & 1.51 & 5,597 & 1.87 \\
\hline Indonesia & 5.61 & 10,209 & 4.89 \\
\hline Malaysia & 2.83 & 2,279 & 2.15 \\
\hline Philippines & 2.02 & 602 & 0.77 \\
\hline Singapore & 2.26 & 2,944 & 3.69 \\
\hline Thailand & 15.90 & 19,790 & 12.54 \\
\hline Vietnam & 8.42 & 1,446 & 6.61 \\
\hline Other Asia & -0.31 & $-1,803$ & -0.34 \\
\hline United States & -0.06 & $-7,059$ & -0.09 \\
\hline EU & -0.01 & $-1,807$ & -0.02 \\
\hline
\end{tabular}

Notes: 1) Figures indicate the changes from basedata.

2) "Sensitivity" means the simulation that changes the elasticity of substitution between domestic and imported products, by 10 percent.

Source: Model simulation 
Table 6. Changes in Real Outputs and Real Exports

\begin{tabular}{|c|c|c|c|c|c|c|c|c|c|c|c|}
\hline Sector & China & Japan & Korea & Hong Kong & Singapore & Taiwan & Indonesia & Malaysia & Philippines & Thailand & Vietnam \\
\hline \multicolumn{12}{|l|}{ Changes in real outputs (\%) } \\
\hline Agriculture & 4.5 & -3.9 & -11.9 & 0.3 & 4.7 & 1.6 & 1.3 & 0.4 & 2.0 & 5.2 & 0.4 \\
\hline Forestory & -0.2 & -1.8 & -3.6 & 1.7 & -7.4 & 3.2 & 8.6 & 2.1 & 2.1 & 16.3 & 11.4 \\
\hline Fishing & 0.9 & -2.8 & 7.6 & -2.6 & 7.8 & -1.0 & 3.9 & 2.5 & 1.3 & 12.6 & 6.1 \\
\hline Mining & -0.2 & -0.7 & -2.1 & 3.8 & 4.1 & -0.9 & 1.4 & 1.7 & 4.1 & 19.2 & -8.3 \\
\hline Food products and beverages & 1.6 & -3.4 & 30.1 & 19.3 & 36.7 & 6.9 & 5.3 & 15.3 & -1.3 & 23.5 & 8.9 \\
\hline Textiles & -0.2 & -2.3 & 17.4 & 3.2 & 1.9 & 17.1 & 3.7 & 7.7 & 13.9 & 8.4 & 174.8 \\
\hline Pulp, paper and paper product & -1.1 & -0.4 & 1.9 & 3.3 & 3.7 & 1.6 & 8.9 & 4.3 & 0.8 & 16.1 & 16.9 \\
\hline Chemicals & -1.6 & 1.1 & 3.4 & 5.5 & 11.1 & 7.1 & 1.4 & 4.4 & 2.0 & 10.6 & -2.0 \\
\hline Iron, steel and metal products & -1.5 & 2.2 & -1.4 & 4.7 & 7.7 & 0.0 & 2.9 & 1.4 & 6.7 & 20.1 & -18.3 \\
\hline Transportation machinery & -16.2 & 5.2 & 1.0 & -7.9 & -14.3 & -6.9 & -47.8 & -24.0 & 29.3 & -11.0 & -55.1 \\
\hline Electronic equipment & 6.9 & -0.7 & -1.9 & 0.9 & 1.9 & -2.5 & 17.4 & 5.7 & 8.9 & 29.2 & -0.9 \\
\hline General machinery & -1.6 & 2.2 & -4.8 & 7.4 & 5.5 & 1.7 & 22.8 & 7.4 & 12.7 & 26.8 & -3.7 \\
\hline Other manufacturing & 1.6 & -0.5 & 0.9 & 8.1 & 5.0 & 2.5 & 7.3 & 1.2 & 5.8 & 18.1 & 12.9 \\
\hline \multicolumn{12}{|l|}{ Changes in real exports (\%) } \\
\hline Agriculture & 194.5 & 41.8 & 451.7 & 19.4 & 43.6 & 28.3 & 2.6 & 27.8 & 118.2 & -53.5 & -14.7 \\
\hline Forestory & 3.6 & 3.8 & -1.3 & 11.3 & -7.4 & 13.5 & 13.9 & -2.9 & 15.6 & 25.1 & -11.2 \\
\hline Fishing & 28.7 & 33.3 & 21.4 & 0.6 & 14.9 & 2.2 & 11.3 & 28.6 & 36.5 & 17.9 & 11.8 \\
\hline Mining & 4.2 & -1.1 & -11.5 & -11.1 & 3.2 & -1.2 & -0.6 & 0.0 & 4.1 & 24.8 & -22.0 \\
\hline Food products and beverages & 78.9 & 88.5 & 462.1 & 136.3 & 78.2 & 131.8 & 52.0 & 40.3 & 27.7 & 74.0 & 71.0 \\
\hline Textiles & 29.2 & 44.0 & 32.1 & 8.5 & 4.4 & 26.8 & 11.5 & 22.1 & 28.3 & 23.5 & 209.5 \\
\hline Pulp, paper and paper product & 6.7 & 19.0 & 15.3 & 12.5 & 6.7 & 6.9 & 11.3 & 9.3 & 6.5 & 19.6 & 56.5 \\
\hline Chemicals & 10.1 & 8.6 & 10.5 & 19.5 & 12.5 & 16.6 & 1.2 & 12.5 & 9.7 & 14.5 & 16.2 \\
\hline Iron, steel and metal products & 11.6 & 15.5 & 6.5 & 17.0 & 10.2 & 6.1 & 9.0 & 12.0 & 18.3 & 36.4 & -16.0 \\
\hline Transportation machinery & 26.9 & 13.6 & 7.7 & -25.1 & -22.8 & 12.1 & 105.8 & 105.1 & 104.3 & 137.7 & 107.8 \\
\hline Electronic equipment & 20.2 & -1.2 & 0.2 & 1.2 & 2.0 & -2.0 & 36.0 & 5.8 & 9.0 & 32.8 & 8.4 \\
\hline General machinery & 11.2 & 5.7 & -1.6 & 13.3 & 8.1 & 6.0 & 44.4 & 12.2 & 17.2 & 36.0 & 1.2 \\
\hline Other manufacturing & 9.2 & 8.9 & 11.6 & 31.0 & 8.3 & 7.9 & 9.1 & 8.9 & 17.9 & 25.5 & 28.1 \\
\hline
\end{tabular}

Note: 1) The changes in real outputs and exports indicate the deviation from base data.

2) Services are not reported since trade barriers in service sectors are not available and it might underestimate the impacts of an East Asia FTA.

Source: Model simulation 
Table 7. Relationship between Protection, Comparative Advantage and Growth

\begin{tabular}{|c|c|c|c|c|c|c|}
\hline \multirow[b]{2}{*}{ Constant } & \multicolumn{3}{|c|}{$\begin{array}{l}\text { Dependent variable: Growth of } \\
\text { outputs }\end{array}$} & \multicolumn{3}{|l|}{ exports } \\
\hline & $\begin{array}{l}4.433 * * \\
(2.271)\end{array}$ & $\begin{array}{l}3.505^{*} \\
(1.939)\end{array}$ & $\begin{array}{l}0.640 \\
(0.308)\end{array}$ & $\begin{array}{l}-2.931 \\
(-0.577)\end{array}$ & $\begin{array}{l}19.300 * * * \\
(3.093)\end{array}$ & $\begin{array}{l}36.810 * * * \\
(4.784)\end{array}$ \\
\hline NRP & $\begin{array}{l}0.014 \\
(0.123)\end{array}$ & & & $\begin{array}{l}3.293 * * * \\
(11.429)\end{array}$ & & \\
\hline ERP & & $\begin{array}{l}0.066 \\
(1.184)\end{array}$ & & & $\begin{array}{l}0.747 * * * \\
(3.899)\end{array}$ & \\
\hline $\mathrm{RCA}$ & & & $\begin{array}{l}3.837 * * * \\
(2.795)\end{array}$ & & & $\begin{array}{l}-5.219 \\
(-1.028)\end{array}$ \\
\hline $\mathrm{R} 2$ & 0.000 & 0.481 & 0.010 & 0.097 & 0.053 & 0.007 \\
\hline Adj. R2 & -0.007 & 0.477 & 0.003 & 0.090 & 0.046 & 0.000 \\
\hline$N$ & 143 & 143 & 143 & 143 & 143 & 143 \\
\hline Notes: & $\begin{array}{l}\text { t-statistic } \\
5 \%, \text { resp }\end{array}$ & $\begin{array}{l}\text { re in pare } \\
\text { ively. }\end{array}$ & $\operatorname{ses} . * * *$ & es statist & y significar & ce at $1 \%$ and \\
\hline Source: & $\begin{array}{l}\text { NRP anc } \\
\text { and expc }\end{array}$ & $\begin{array}{l}\mathrm{RP} \text { are fro } \\
\text { are from }\end{array}$ & $\begin{array}{l}\text { Table } 4 . \mathrm{RC} \\
\text { le } 6 \text {. }\end{array}$ & from Tab & . The growt & of outputs \\
\hline
\end{tabular}


Table 8. Export and Import Compositions of East Asian Economies Resulting from an East Asia FTA (percentage shares in total)

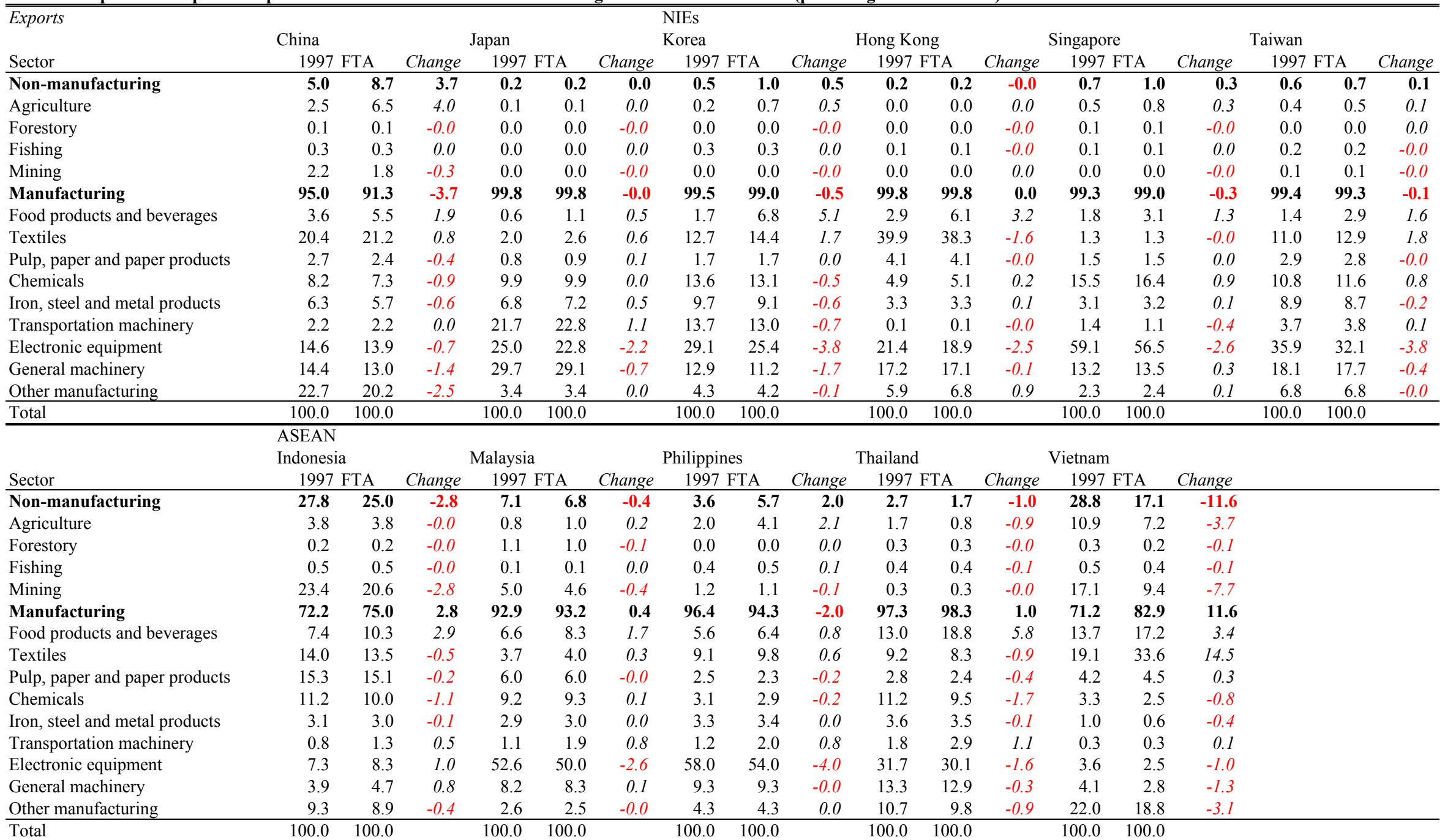

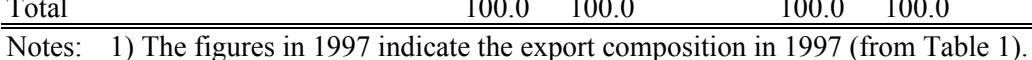

2) The figures in FTA indicate the export composition resulting from FTA (model simulation).

3) The changes indicate the difference between 1997 and FTA (percentage points).

4) Non-manufacturing do not include service sectors.

5) Services are not reported since trade barriers in service sectors are not available and it might underestimate the impacts of an East Asia FTA.

Source: model simulation and GTAP version 5. 
Table 8. (continued) Export and Import Compositions of East Asian Economies Resulting from an East Asia FTA (percentage shares in total)

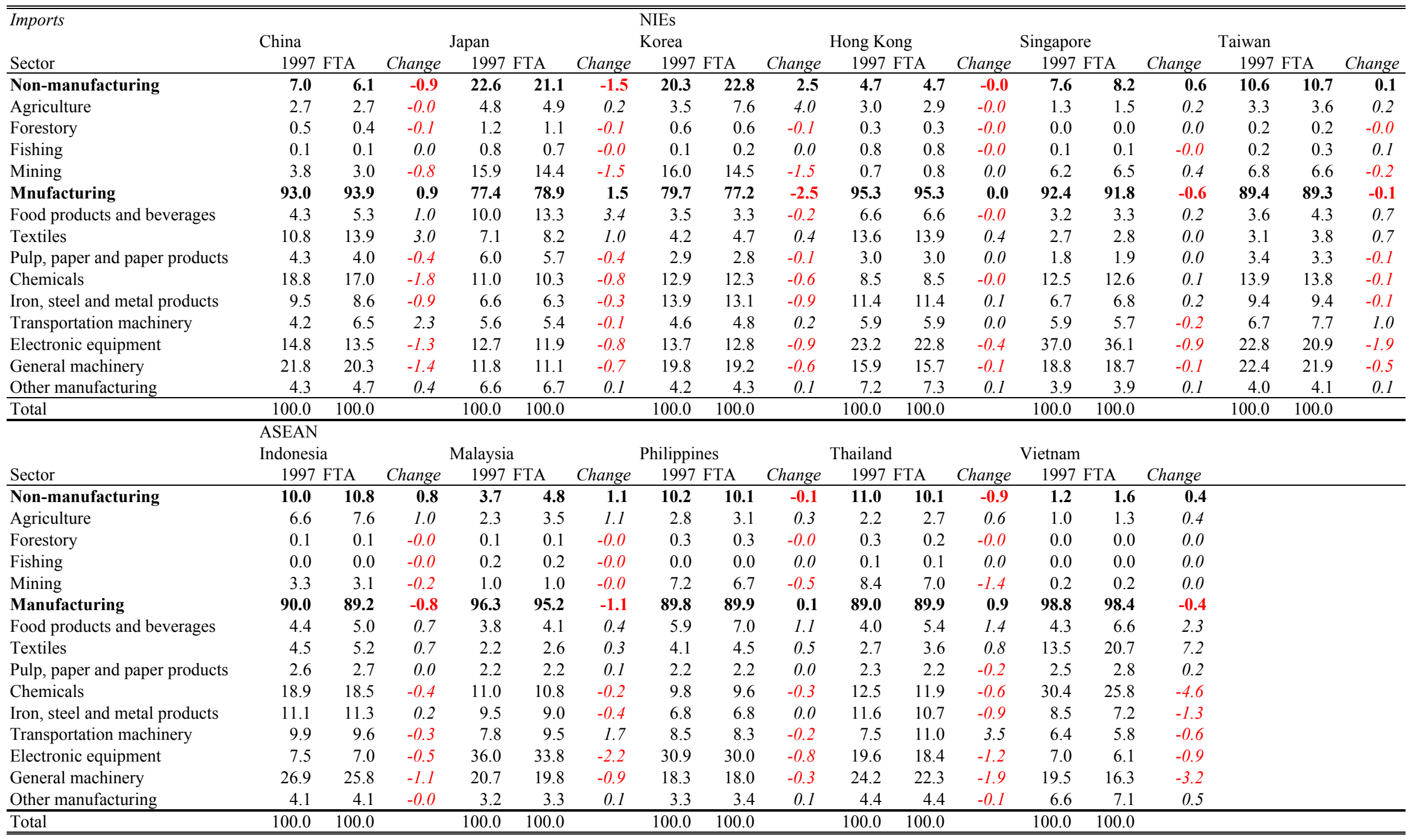


Table 9. Changes in Intra-Industry Trade Index

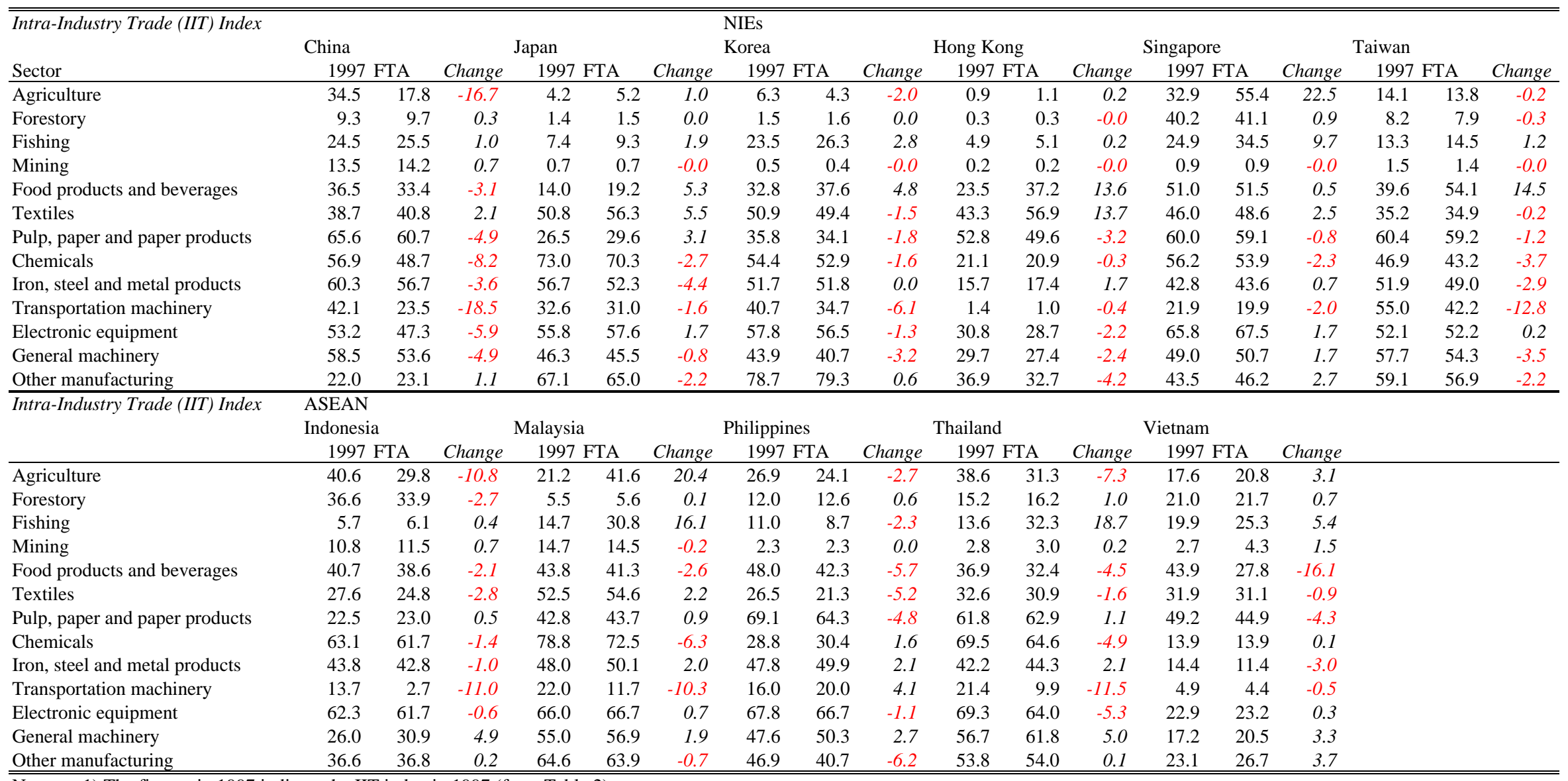

Notes: 1) The figures in 1997 indicate the IIT index in 1997 (from Table 2).

2) The figures in FTA indicate the IIT index under FTA.

3) The changes indicate the difference between 1997 and FTA

4) Services are not reported since trade barriers in service sectors are not available and it might underestimate the impacts of an East Asia FTA.

Source: model simulation and GTAP version 5. 
Table 10 Regionalization in Trade for East Asian Economies Resulting from an East Asia FTA

\begin{tabular}{|c|c|c|c|c|c|c|c|c|}
\hline \multicolumn{9}{|l|}{ A) Regionalization in 1997 (from Table 3) } \\
\hline \multirow[b]{3}{*}{ Sector } & \multicolumn{4}{|l|}{ East Asia } & \multicolumn{4}{|l|}{ ASEAN } \\
\hline & \multirow[t]{2}{*}{$\begin{array}{l}\text { Absolute } \\
\text { measure }\end{array}$} & \multicolumn{2}{|c|}{ Relative measure } & \multirow{2}{*}{$\begin{array}{l}\text { Double } \\
\text { relative } \\
\text { measure }\end{array}$} & \multirow[t]{2}{*}{$\begin{array}{l}\text { Absolute } \\
\text { measure }\end{array}$} & \multicolumn{2}{|c|}{ Relative measure } & \multirow{2}{*}{$\begin{array}{l}\text { Double } \\
\text { relative } \\
\text { measure }\end{array}$} \\
\hline & & Exports & Imports & & & Exports & Imports & \\
\hline Total & 0.11 & 0.44 & 0.50 & 2.02 & 0.01 & 0.21 & 0.20 & 3.17 \\
\hline Agriculture & 0.04 & 0.56 & 0.19 & 2.53 & 0.01 & 0.19 & 0.13 & 3.81 \\
\hline Forestory & 0.10 & 0.71 & 0.20 & 1.38 & 0.01 & 0.07 & 0.22 & 1.79 \\
\hline Fishing & 0.18 & 0.84 & 0.52 & 2.37 & 0.02 & 0.22 & 0.54 & 6.52 \\
\hline Mining & 0.05 & 0.81 & 0.19 & 2.87 & 0.01 & 0.13 & 0.14 & 2.67 \\
\hline Food products and beverages & 0.07 & 0.58 & 0.33 & 2.72 & 0.01 & 0.15 & 0.24 & 3.37 \\
\hline Textiles & 0.17 & 0.48 & 0.77 & 2.20 & 0.00 & 0.08 & 0.15 & 2.32 \\
\hline Pulp, paper and paper products & 0.07 & 0.55 & 0.45 & 1.72 & 0.01 & 0.11 & 0.26 & 2.83 \\
\hline Chemicals & 0.10 & 0.56 & 0.49 & 3.32 & 0.02 & 0.31 & 0.25 & 3.78 \\
\hline Iron, steel and metal products & 0.12 & 0.63 & 0.47 & 2.68 & 0.01 & 0.30 & 0.10 & 4.81 \\
\hline Transportation machinery & 0.04 & 0.18 & 0.32 & 2.54 & 0.00 & 0.24 & 0.04 & 4.26 \\
\hline Electronic equipment & 0.22 & 0.42 & 0.68 & 1.61 & 0.05 & 0.23 & 0.32 & 5.73 \\
\hline General machinery & 0.11 & 0.46 & 0.52 & 1.31 & 0.01 & 0.29 & 0.13 & 1.63 \\
\hline Other manufacturing & 0.09 & 0.29 & 0.52 & 2.12 & 0.01 & 0.11 & 0.16 & 3.82 \\
\hline \multicolumn{9}{|c|}{ B) Regionalization resulting from an East Asia FTA } \\
\hline & \multicolumn{4}{|l|}{ East Asia } & \multicolumn{4}{|l|}{ ASEAN } \\
\hline & $\begin{array}{l}\text { Absolute } \\
\text { measure }\end{array}$ & Relative $\mathrm{m}$ & easure & $\begin{array}{l}\text { Double } \\
\text { relative } \\
\text { measure }\end{array}$ & $\begin{array}{l}\text { Absolute } \\
\text { measure }\end{array}$ & Relative $\mathrm{m}$ & sure & $\begin{array}{l}\text { Double } \\
\text { relative } \\
\text { measure }\end{array}$ \\
\hline Sector & \multicolumn{3}{|c|}{ Exports } & & \multicolumn{3}{|c|}{ Exports } & \\
\hline Total & 0.14 & 0.53 & 0.59 & 2.17 & 0.02 & 0.22 & 0.22 & 3.09 \\
\hline Agriculture & 0.13 & 0.85 & 0.46 & 3.06 & 0.01 & 0.36 & 0.21 & 5.55 \\
\hline Forestory & 0.11 & 0.72 & 0.20 & 1.38 & 0.01 & 0.07 & 0.23 & 1.78 \\
\hline Fishing & 0.23 & 0.87 & 0.59 & 2.30 & 0.02 & 0.25 & 0.61 & 6.43 \\
\hline Mining & 0.06 & 0.82 & 0.19 & 2.84 & 0.01 & 0.14 & 0.14 & 2.65 \\
\hline Food products and beverages & 0.18 & 0.80 & 0.65 & 2.93 & 0.02 & 0.16 & 0.32 & 2.97 \\
\hline Textiles & 0.24 & 0.57 & 0.88 & 2.11 & 0.01 & 0.08 & 0.14 & 1.92 \\
\hline Pulp, paper and paper products & 0.09 & 0.61 & 0.51 & 3.42 & 0.01 & 0.12 & 0.28 & 3.69 \\
\hline Chemicals & 0.12 & 0.62 & 0.55 & 2.72 & 0.02 & 0.33 & 0.27 & 4.75 \\
\hline Iron, steel and metal products & 0.14 & 0.68 & 0.53 & 2.58 & 0.01 & 0.33 & 0.12 & 4.34 \\
\hline Transportation machinery & 0.08 & 0.36 & 0.60 & 2.64 & 0.00 & 0.20 & 0.04 & 3.97 \\
\hline Electronic equipment & 0.24 & 0.45 & 0.72 & 1.34 & 0.05 & 0.24 & 0.34 & 1.63 \\
\hline General machinery & 0.14 & 0.52 & 0.59 & 2.23 & 0.01 & 0.32 & 0.15 & 3.95 \\
\hline Other manufacturing & 0.12 & 0.37 & 0.63 & 1.91 & 0.01 & 0.13 & 0.19 & 3.04 \\
\hline \multirow{3}{*}{ Changes from 1997 (A) to FTA (B) } & \multicolumn{4}{|l|}{ East Asia } & ASEAN & & & \\
\hline & $\begin{array}{l}\text { Absolute } \\
\text { measure }\end{array}$ & Relative $\mathrm{m}$ & neasure & $\begin{array}{l}\text { Double } \\
\text { relative } \\
\text { measure }\end{array}$ & $\begin{array}{l}\text { Absolute } \\
\text { measure }\end{array}$ & Relative $\mathrm{m}$ & geasure & $\begin{array}{l}\text { Double } \\
\text { relative } \\
\text { measure }\end{array}$ \\
\hline & & Exports & Imports & & & Exports & Imports & \\
\hline Total & 0.03 & 0.08 & 0.10 & 0.15 & 0.00 & 0.01 & 0.02 & -0.09 \\
\hline Agriculture & 0.09 & 0.29 & 0.27 & 0.52 & 0.01 & 0.17 & 0.08 & 1.73 \\
\hline Forestory & 0.00 & 0.01 & 0.00 & 0.00 & 0.00 & 0.00 & 0.00 & -0.01 \\
\hline Fishing & 0.04 & 0.04 & 0.07 & -0.07 & 0.01 & 0.03 & 0.07 & -0.10 \\
\hline Mining & 0.00 & 0.01 & 0.00 & -0.03 & 0.00 & 0.01 & 0.00 & -0.02 \\
\hline Food products and beverages & 0.11 & 0.22 & 0.32 & 0.22 & 0.01 & 0.01 & 0.09 & -0.40 \\
\hline Textiles & 0.07 & 0.10 & 0.11 & -0.09 & 0.00 & 0.00 & 0.00 & -0.40 \\
\hline Pulp, paper and paper products & 0.02 & 0.06 & 0.06 & 1.70 & 0.00 & 0.01 & 0.02 & 0.87 \\
\hline Chemicals & 0.02 & 0.05 & 0.06 & -0.60 & 0.00 & 0.02 & 0.02 & 0.97 \\
\hline Iron, steel and metal products & 0.02 & 0.06 & 0.06 & -0.10 & 0.00 & 0.03 & 0.02 & -0.47 \\
\hline Transportation machinery & 0.05 & 0.18 & 0.28 & 0.10 & 0.00 & -0.03 & 0.00 & -0.28 \\
\hline Electronic equipment & 0.02 & 0.03 & 0.03 & -0.27 & 0.00 & 0.01 & 0.02 & -4.10 \\
\hline General machinery & 0.02 & 0.06 & 0.07 & 0.92 & 0.00 & 0.03 & 0.02 & 2.32 \\
\hline Other manufacturing & 0.03 & 0.08 & 0.11 & -0.20 & 0.00 & 0.02 & 0.03 & -0.77 \\
\hline
\end{tabular}

Note: 1) For the definition of variables, see Appendix in the main text.

2) Services are not reported since trade barriers in service sectors are not available and it might underestimate the impacts of an East Asia FTA.

Source: Model simulation. 